\title{
PERBANDINGAN MEDIA POWTOON DAN MIND MAP PADA PEMBELAJARAN MENULIS TEKS EKSPLANASI SISWA SMPN 85 JAKARTA
}

\author{
Alin Delona*1, Ratna Dewi Kartikasari ${ }^{2}$ \\ *1,2 Prodi Pendidikan Bahasa dan Sastra Indonesia, Fakultas Ilmu Pendidikan, Universitas \\ Muhammadiyah Jakarta \\ e-mail:*1alindelona96@gmail.com, ${ }^{2}$ ratna.dewikartikasari@umj.ac.id
}

\begin{abstract}
ABSTRAK
Penelitian ini dilatarbelakangi pembelajaran bahasa Indonesia khusunya pada materi teks eksplanasi masih menggunakan metode pembelajaran yang masih monoton yaitu menggunakan metode ceramah. Penulis tergerak untuk mengetahui hasil belajar Siswa pada materi teks eksplanasi dengan menggunakan metode yang baru yang lebih fresh dengan media powtoon dan media mind map. Penelitian ini bertujuan untuk melihat perbandingan hasil belajar Siswa pada materi teks eksplanasi melalui media powtoon dan media mind map. Pada penelitian ini menggunakan metode penelitian kuantitatif. Hasil penelitian ini membuktikan penggunaan media mind map dan media powtoon. Hasil perbandingan antara $t_{\text {hitung }}(13,611)$ lebih besar dari $t_{\text {tabel }}$ $(1,6696)$ pada $\alpha=0,05$ yang artinya hasil pembelajaran siswa melalui pembelajaran powtoon lebih baik daripada hasil belajar menggunakan media pembelajaran mind map. Pada hal inilah dibuktikan nilai rata-rata nilai hasil belajar menggunakan media pembelajaran powtoon sebesar 92,00 lebih besar dari rata-rata nilai belajar menggunakan media pembelajaran mind map sebesar 89,06 .
\end{abstract}

Kata kunci: hasil belajar, media powtoon, media Mind Map.

\begin{abstract}
This research is motivated by learning Indonesian, especially in explanatory text material, which still uses a monotonous learning method, namely using the lecture method. The author was moved to find out student learning outcomes on explanatory text material by using a new, fresher method with powtoon media and mind map media. The purpose of this study was to examine the comparison of student learning outcomes on the material of writing explanatory texts through the Powtoon and Mind Map media. In this study using quantitative research methods. The results of this study prove the use of mind map media and powtoon media. The result of the comparison between tcount (13.611) is greater than the table (1.6696) at $=0.05$, which means that student learning outcomes through powtoon learning are better than learning outcomes using mind map learning media. It can be proven that the average value of learning outcomes using Powtoon learning media is 92.00, which is greater than the average value of learning using mind map learning media of 89.06 .
\end{abstract}

Keywords: Learning Outcomes, Powtoon Media, and Mind Map Media.

\section{PENDAHULUAN}

Pembelajaran bahasa Indonesia merupakan salah satu pembelajaran yang selalu ada dalam setiap jenjang pendidikan. Pada hakikatnya dalam pembelajaran ini terdapat empat keterampilandi mana Siswa harus menguasai, salah satunya yaitu keterampilan menulis. Menulis merupakan sebuah kegiatan penyampaian pesan atau gagasan secara tertulis [1]. Sejalan dengan pendapat tersebut [2] mengutarakan bahwa keterampilan menulis menggambarkan lambing suatu 
grafik tersebut bahwa siswa dapat mememahami bahasa Indonesia dari yang terdapat pada grafik tersebut. Pada saat ini keterampilan menulis sangat penting dalam dunia pendidikan karena dapat membuat siswa berpikir secara kristis.

Pada silabus di dalam kurikulum 2013 keterampilan menulis merupakan keterampilan yang harus dikuasai oleh siswa dalam pelajaran bahasa Indonesia. Keterampilan menulis ini harus dikuasai siswa pada materi tentang berbagai jenis teks. Salah satunya dalam materi teks eksplanasi. Pada materi teks eksplanasi ini diharapkan siswa memiliki kemampuan menulis teks eksplanasi yang baik. Menurut pada reaksi wawancara yang dilakukan oleh peneliti dengan guru Bahasa Indonesia kelas VIII SMPN 85 Jakarta pada Jumat, 28 Februari 2020, ditemukan adanya masalah yang terdapat pada siswa akibat kurang motivasi yang didapat oleh siswa pada saat menyusun kalimat teks eksplanasi dengan tepat. Hal ini dapat diakibatkan

Ekplanasi merupakan teks yang menggambarkan sebuah fenomena alam ataupun sosial. Teks eksplanasi merupakan teks yang berisi penjelasan atau paparan tentang bagaimana dan mengapa suatu fenomena dapat terjadi [3]. Sejalan dengan pendapat tersebut menjelaskan bahwa teks eksplanasi merupakan teks yang memiliki fungsi sosial menganalisis atau menjelaskan proses muncul atau terjadinya sesuatu [4]. Untuk mempelajari dan memahami hingga mampu membuat teks eksplanasi ini tentu saja dibutuhkannya sebuah media yang menarik, guna meningkatkan siswa dalam proses pembelajaran.

Media merupakan alat bantu dalam proses pembelajaran guna meningkatkan motivasi siswa dalam kegiatan pembelajaran. "Media" berasal dari bahasa latinmedius yang secara harfiah berarti tengah, perantara atau pengantar [5]. Dalam bahasa Arab, media merupakan perantara atau pengantar pesan dari pengirim kepada penerima pesan. Media mempunyai peran penting dalam proses pembelajaran, dan media juga terbagi menjadi beberapa jenis, walaupun umumnya fungsinya sama yaitu meningkatkan motivasi siswa pada proses pembelajaran, akan tetapi guru harus memilih media yang sesuai melalui materi yang akan diajar. Media pembelajaran dapat berupa buku pengayaan, dimana dapat dikatakan efektif dalam pembelajaran menulis teks prosedur kompleks [6]. Media merupakan alat bantu untuk pembelajaran bahasa Indonesia, terkhusus pada materi teks eksplanasi adalah media Powtoon dan juga Mind map. Powtoon [7] merupakan softwareonline yang inovatif serta bersahaja sehingga mampu menciptakan animasi yang menarik dengan memakai video animasi. Sedangkan [8] Mind map merupakan media pembelajaran yang memungkinkan kita untuk mengeksplorasi seluruh kemampuan otak kita untuk keperluan berpikir serta belajar. Kedua media ini dapat digunakan dalam pembelajaran teks eksplanasi, tetapi alangkah lebih baiknya jika kita mengetahui secara pasti media mana yang jauh lebih tepat digunakan diantara keduanya. Penelitian ini dilaksanakan dalam upaya mengetahui bagaimana terampilnya siswa saat menulis teks eksplanasi dengan menggunakan media Mind map dan Powtoon sehingga dapat terlihat perbandingannya.

\section{METODOLOGI PENELITIAN}

Pada penelitian ini peneliti menggunakan metode penelitian pendekatan kuantitatif dan untuk pengumpulan data pada penelitian ini peneliti menggunakan teknik pengumpulan data dengan teknik eksperimen. Pada metode penelitian ini berguna unruk mencari apakah terdapat perbedaan anatara media powtoon dengan media mind map media sebagai varibel bebas (X) terhadap hasil belajar sebagai variabel terikat (Y). penelitian ini dilakukan dengan cara membagi kelompok penelitian menjadi dua kelompok, kelompok pertama dan kelompok kedua. Kelompok pertama yaitu kelas kelompok eksperimen pertama menggunakan media powtoon, kelompok eksperimen kedua menggunakan media mind map. Pada kedua kelompok tersebut menggunakan media pembelajaran yang berbeda dalam materi teks eksplanasi terdahap hasil belajar pada keahlian menulis teks eksplanasi Siswa kelas VII SMPN 85 Jakarta.

Penelitian ini menggunakan metode penelitian designone-shot case study. [9] Desain tersebut adalah pembelajaran suatu kelompok yang dibagi treatment atau perlakuan atau tindakan 
(X) dan setelah itu observasi hasilnya O. dapat disimpulkanpengolahan data adalah sebagai salah satu variabel independen atau suatu tindakan dan hasil dari sbuah variabel dependen.

Populasi dalam penelitian ini adalah seluruh Siswa kelas VIII SMPN 85 Jakarta tahun pelajaran 2020/2021, dan sampel pada penelitian ini ialah suatu bagian dari jumlah dan karakteristik yang dimiliki oleh populasi tersebut. Teknik sampling yang digunakan adalah Simple Random Sampling. Pada penelitian ini peneliti mengumpulkan data dengan proses wawancara, catatan lapangan, dokumentasi, serta melalui tes uraian. Setelah itu peneliti menganalisis data tersebut menggunakan metode ke dalam katagori ke dalam sebuah kategori, menjabarkan ke dalam unit-unit, melakukan sintesa dan juga menyusun dalam pola juga memilih mana yang penting dan yang akan Siswa pelajari dan membuat kesimpulan sehingga dapat mudah dipahami oleh diri sendiri maupun juga orang lain.

\section{HASIL DAN PEMBAHASAN}

\section{Hasil Penelitian}

Penelitian ini dilakukan sebanyak dua kali di SMP Negeri 85 Jakarta di kelas VIII C menjadi kelas eksperimen pertama dengan menggunakan media pembelajaran powtoon dan kelas VIII D sebagai kelas eksperimen kedua dengan menggunakan media pembelajaran mind map. Pada penelitian ini terdapat 2 variabel yang diperoleh dari hasil pengisian tes yang telah dilakukan oleh 72 orang siswa yang terdiri dari 36 Siswa kelas eksperimen pertama dan 36 Siswa kelas eksperimen kedua. Pada kedua variabel tersebut telah ditetapkan hasil belajar pada Siswa melalui media pembelajaran mind map melalui media pembelajaran powtoon yang ditetapkan $\mathrm{Y}_{1}$ dan $\mathrm{Y}_{2}$

Pada masing-masing data variabel diuraikan memakai teknik statistik uraian atau sebuah deskriptif meliputi skor minimum, skor, dan tabel distribusi pada sebuah frekuensi dengan histrogram yang juga memperhatikan sebuah hamparan data pada sebuah data, gambar dan juga grafik. Hasil belajar Siswa melalui sebuah video ada pada media powtoon $\left(\mathrm{Y}_{1}\right)$. Pada hasil belajar yang Siswa lakukan melalui video yang ada pada media powtoon $\left(\mathrm{Y}_{1}\right)$. Hasil belajar menggunakan video pembelajaran powtoon yang diperoleh berdasarkan sebuah hasil yang telah diukur dengan tes pada suatu kelas eksperimen pertama. Pada sebuah hasil analisis data serta sebuah hasil perhitungan statistic yang menunjukan skor empirik hasil belajar melalui sebuah video pembelajaran powtoon bervariasi antara 8,3 sampai dengan 97 dan semua hasil itu dapat dilihat pada sebuah Tabel 1 berikut.

Tabel 1.

Data Hasil Kemampuan Menulis Teks Eksplanasi pada Kelas Eksperimen Pertama

\begin{tabular}{clc}
\hline No. & Nama Siswa & Nilai \\
\hline 1. & AJS & 91 \\
2. & AAN & 96 \\
3. & AKS & 93 \\
4. & ARS & 96 \\
5. & CA & 90 \\
6. & CAN & 86 \\
7. & CAKM & 92 \\
8. & CSAR & 92 \\
9. & DMW & 93 \\
10. & DN & 91 \\
11. & GDU & 92 \\
12. & GAS & 96 \\
13. & HA & 92 \\
14. & IIF & 92 \\
15. & ISNA & 83 \\
\hline
\end{tabular}


Jurnal SEMANTIKA, Volume 3 No 1 Agustus 2021, pp. 21-29

\begin{tabular}{llc}
\hline No. & \multicolumn{1}{c}{ Nama Siswa } & Nilai \\
\hline 16. & IR & 95 \\
17. & LMSA & 93 \\
18. & MRR & 95 \\
19. & MAP & 85 \\
20. & MHIW & 86 \\
21. & MIAI & 89 \\
22. & MI & 92 \\
23. & MR & 93 \\
24. & NAS & 88 \\
25. & NJW & 95 \\
26. & NL & 91 \\
27. & NRA & 95 \\
28. & NAD & 90 \\
29. & NYM & 95 \\
30. & PF & 93 \\
31. & RSMY & 92 \\
32. & RN & 93 \\
33. & RA & 94 \\
34. & SJPP & 90 \\
35. & SNSS & 96 \\
36. & SNNS & 97 \\
& Jumlah & 3.312 \\
\hline
\end{tabular}

Data nilai dalam kelas eksperimen pertama yang disajikan pada Tabel 1 , berikutnya dianalisis secara deskriptif untuk menghitung nilai yang terdiri dari rata - rata, median, modus, simpangan baku, varians, maximal, minimal dan rentang. Berikut Tabel 2 hasil analisis statistik deskriptif pada kelas eksperimen satu.

Tabel 2.

Analisis Statistika Deskriptif Eksperimen Pertama

\begin{tabular}{cc}
\hline Statistik & Nilai \\
\hline Rata-rata & 92,00 \\
Median & 93,27 \\
Modus & 93,25 \\
Stdev & 3,11 \\
Varians & 9,71 \\
MAX & 97 \\
MIN & 83 \\
RENTANG & 14 \\
\hline
\end{tabular}

Telah dikemukakan pada Tabel 2 dapat ditemukan bahwa nilai rata-rata yang terdapat pada kelas eksperimen ialah sebesar 92,00, nilai median 93,27, nilai modus 93,25 , nilai simpangan baku 3,11, nilai varians 9,71, nilai maximal 97, nilai minimal 83 dan nilai rentang 14. Supaya lebih jelasnya, penyebaran skor hasil belajar melalui video pembelajaran powtoon mengikuti tabel distribusi frekuensi di atas dapat dilihat pada histogram dalam Gambar 1. 


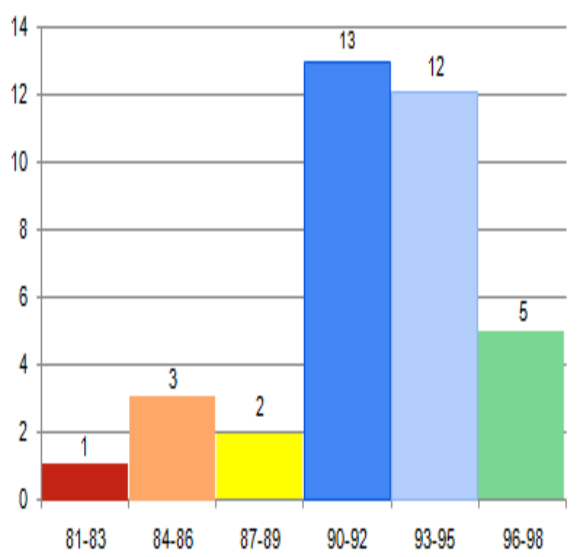

Gambar 1.

Histogram Frekuensi Skor Hasil Belajar melalui Media Pembelajaran Powtoon $\left(\mathbf{Y}_{1}\right)$

Setelah mengetahui hasil dari $\left(\mathrm{Y}_{1}\right)$ kemudian, berikut hasil belajar melalui Video Pembelajaran Mind Map $\left(\mathrm{Y}_{2}\right)$. Pada diagram di atas skor variabel pada hasil belajar siswa melalui media Mind map yang diperoleh berdasrkan hasil pada tes pengukuran pada kelas eskperimen yang kedua. Analis data dan perhitungan statistic menunjukan hasil skor empirik pada hasil belajar melalui media mind map yang bervariaso antara 81 sampai dengan 96 , hasil tersebut bisa dilihat pada Tabel 3 berikut.

Tabel 3.

Data Hasil Kemampuan Menulis Teks Eksplanasi pada Kelas Eksperimen Kedua

\begin{tabular}{clc}
\hline No. & \multicolumn{1}{c}{ Nama Siswa } & Nilai \\
\hline 1. & ABJN & 90 \\
2. & AAZA & 94 \\
3. & ACP & 83 \\
4. & AAH & 83 \\
5. & ABK & 90 \\
6. & ACD & 91 \\
7. & ADP & 90 \\
8. & ADR & 93 \\
9. & APZ & 90 \\
10. & ARA & 82 \\
11. & AKW & 83 \\
12. & CRPW & 81 \\
13. & DBRNS & 90 \\
14. & FARP & 87 \\
15. & FFP & 92 \\
16. & FRP & 91 \\
17. & JSR & 92 \\
18. & KPM & 94 \\
19. & KAK & 81 \\
20. & LIAM & 84 \\
21. & MFDA & 92 \\
22. & NSAE & 86 \\
23. & NA & 87 \\
\hline & & \\
\hline
\end{tabular}


Jurnal SEMANTIKA, Volume 3 No 1 Agustus 2021, pp. 21-29

\begin{tabular}{llc}
\hline No. & \multicolumn{1}{c}{ Nama Siswa } & Nilai \\
\hline 24. & SW & 86 \\
25. & NNI & 84 \\
26. & NMS & 93 \\
27. & NAP & 96 \\
28. & NAIT & 95 \\
29. & OS & 95 \\
30. & QDS & 96 \\
31. & RRP & 90 \\
32. & RAAA & 89 \\
33. & SDW & 95 \\
34. & SNM & 87 \\
35. & SRZR & 92 \\
36. & ZEK & 82 \\
& Jumlah & $\mathbf{3 . 2 0 6}$ \\
\hline
\end{tabular}

Data nilai pada kelas eksperimen kedua yang disajikan pada Tabel 3, setelah itu berikut kupasan deskriptif untuk mrnghitung nilai yang teridiri dari rata-rata, median, modus, simpangan baku, varians, maximal, minimal dan rentang. Berikut hasil analisis statistik deskriptif yang terdapat di kelas eksperimen pada salah satu yang disajikan pada Tabel 4 di bawah ini.

Tabel 4.

Analisis Statistika Deskriptif pada Kelas Eksperimen Kedua

\begin{tabular}{cc}
\hline Statistik & Nilai \\
\hline Rata-rata & 89,06 \\
Median & 90,25 \\
Modus & 91,34 \\
Stdev & 4,65 \\
Varians & 21,76 \\
MAX & 96 \\
MIN & 81 \\
RENTANG & 15 \\
\hline
\end{tabular}

Berdasarkan Tabel 4 dapat diketahui bahwa nilai rata - rata pada kelas eksperimen kedua adalah sebesar 89,06, nilai median 90,25, nilai modus 91,34, nilai simpangan baku 4,65, nilai varians 21,76 , nilai maximal 96 , nilai minimal 81 dan nilai rentang 15 . Untuk lebih jelasnya, penyebaran skor variabel Hasil Belajar melalui media pembelajaran mind map dengan berdasarkan distribusi Gambar 2. Frekuensi pada historigam.

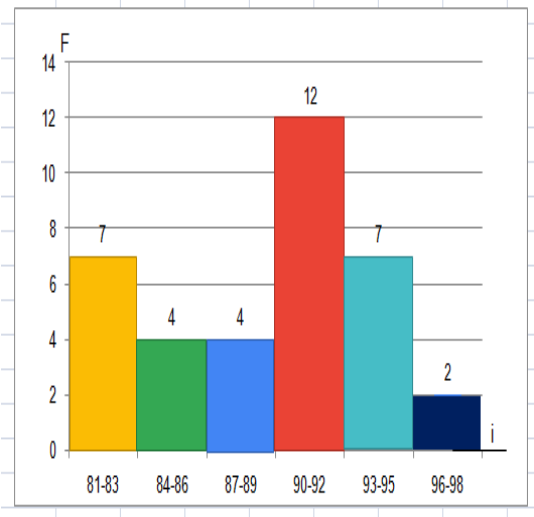

Gambar 2.

Histogram Frekuensi Skor Hasil Belajar melalui media Pembelajaran Mind Map $\left(\mathbf{Y}_{2}\right)$ 
Penelitian telah diuji dan dilakukan dengan cara empiris dan komparasi atau perbandingan antara hasil belajar siswa dengan media mind map $\left(\mathrm{Y}_{2}\right)$ dengan hasil belajar melalui media pembelajaran powtoon $\left(\mathrm{Y}_{1}\right)$ menggunakan teknik Uji T. Hasil uji T terdapat pada Tabel 5.

Tabel 5. Hasil Uji T

\begin{tabular}{|c|c|c|}
\hline No & $Y_{1}$ & $\mathbf{Y}_{2}$ \\
\hline 1 & 91 & 90 \\
\hline 2 & 96 & 94 \\
\hline 3 & 93 & 83 \\
\hline 4 & 96 & 83 \\
\hline 5 & 90 & 90 \\
\hline 6 & 86 & 91 \\
\hline 7 & 92 & 90 \\
\hline 8 & 92 & 93 \\
\hline 9 & 93 & 90 \\
\hline 10 & 91 & 82 \\
\hline 11 & 92 & 83 \\
\hline 12 & 96 & 81 \\
\hline 13 & 92 & 90 \\
\hline 14 & 92 & 87 \\
\hline 15 & 83 & 92 \\
\hline 16 & 95 & 91 \\
\hline 17 & 93 & 92 \\
\hline 18 & 95 & 94 \\
\hline 19 & 85 & 81 \\
\hline 20 & 86 & 84 \\
\hline 21 & 89 & 92 \\
\hline 22 & 92 & 86 \\
\hline 23 & 93 & 87 \\
\hline 24 & 88 & 86 \\
\hline 25 & 95 & 84 \\
\hline 26 & 91 & 93 \\
\hline 27 & 95 & 96 \\
\hline 28 & 90 & 95 \\
\hline 29 & 95 & 95 \\
\hline 30 & 93 & 96 \\
\hline 31 & 92 & 90 \\
\hline 32 & 93 & 89 \\
\hline 33 & 94 & 95 \\
\hline 34 & 90 & 87 \\
\hline 35 & 96 & 92 \\
\hline 36 & 97 & 82 \\
\hline$\sum$ & 3312 & 3206 \\
\hline Rata-rata & 92,00 & 89,06 \\
\hline Variance & 9,71 & 21,76 \\
\hline Std.Deviasi & 3,11 & 4,65 \\
\hline
\end{tabular}

Komparasi antara hasil belajar melalui media pembelajaran powtoon reaksi belajar melalui media pembelajaran mind map diartikan untuk menguji sebuah penelitian yang 
memerlukan langkah-langkah sebagai berikut. Ho $: \mu=\mu_{\mathrm{o}}$ tidak terdapat perbedaan hasil belajar melalui media pembelajaran powtoon dengan hasil Belajar melalui media mind map. H1: $\mu \neq \mu_{\mathrm{o}}$ terdapat perbedaan anatara hasil belajar melalui alat bantu pembelajaran powtoon dan juga hasil belajar dengan menggunakan media mind map.

Kekokohan dari hasil belajar yang dilaksanakan melalui media pembelajaran powtoon pada hasil belajar melalui media pembelajaran mind map dijelaskan oleh thitung dengan menggunakan teknik Uji T. Hasil perhitungan menggunakan Uji T disajikan dalam Tabel 6 sebagai berikut.

Tabel 6.

Hasil Perhitungan thitung Komparasi antara Hasil Belajar melaluiMedia Pembelajaran Mind Map $\left(\mathbf{Y}_{2}\right)$ dengan Hasil Belajar melaluiMedia Pembelajaran Powtoon ( $\left.\mathbf{Y}_{1}\right)$

\begin{tabular}{lll}
\hline $\mathbf{N}$ & thitung & $\begin{array}{l}\text { tabel } \\
\mathbf{\alpha}=\mathbf{0 , 0 5}\end{array}$ \\
& & \\
\cline { 2 - 3 } & 13,611 & 1,6669 \\
\hline
\end{tabular}

Bedasarkan pada Tabel 6 telah dilakukan perhitungan yang telah dilakukan dan memperoleh nilai 13,611 dan nilai tabel sebesar 1,6669. Dari hasil kedua nilaitersebut, maka dapat ditentukan bahwa $t_{0}>t_{a}$ yaitu 13,611 > 1,6669. Sehinggadapat disimpulkan bahwa Ho ditolak, yang berarti terdapat perbedaanhasil belajar antara $Y_{1}$ dengan $Y_{2}$. Hail perhitungan yang telah dilakukan berdasarkan data dan langkah-langkah yang dikerjakan diperoleh nilai thitung sebesar 13,611 >t tabel 1,6669 pada $\alpha=0,05$ menunjukan bahwa komparasi signifikan. Dengan demikian, hipotesis penelitian yang menyatakan terdapat perbedaan hasil belajar $Y_{1}$ dengan hasil belajar $Y_{2}$ bisa dapat peneliti terima. Artinya hasil belajar $\mathrm{Y}_{1}$ lebih baik dari hasil belajar $\mathrm{Y}_{2}$.

Berdasarkan hasil analisis data tersebut diperoleh bukti empiris yang menunjukan adanya perbedaan antara hasil belajar $\mathrm{Y}_{1}$ menggunakan media powtoon dengan hasil belajar $\mathrm{Y}_{2}$ dengan media mind map. Oleh karena itu selaku empiris dapat dinyatakan bahwa salah satu upaya untuk meningkatkan hasil belajar dapat dilakukan dengan menggunakan media powtoon dalam pembelajaran. Media pembelajaran powtoon. Oleh karena itu dapat dibuktikan dari perbandingan antara thitung $(=13,611)$ lebih besar dari tabel $(=1,6669) \alpha=0,05$, artinya hasil belajar melalui media belajar powtoon lebih baik daripada hasil belajar melalui media pembelajaran mind map. Hasil ini dibuktikan pula rata-rata nilai hasil belajar menggunakan media powtoon sebesar 92,00, lebih besar dari rata-rata nilai hasil belajar media mind map sebesar 89,06.

\section{Pembahasan}

Hasil Penelitian menunjukkan bahwa hasil pembelajaran siswa melalui pembelajaran powtoon lebih baik daripada hasil belajar menggunakan media pembelajaran mind map. Hal ini terlihat pada perbandingan antara $t_{\text {hitung }}(13,611)$ lebih besar dari $t_{\text {tabel }}(1,6696)$ pada $\alpha=0,05$. Nilai rata-rata hasil belajar menggunakan media pembelajaran powtoon sebesar 92,00 lebih besar dari rata-rata nilai belajar menggunakan media pembelajaran mind map sebesar 89,06.

Sama halnya dengan bahwa media pembelajaran video animasi powtoon dapat meningkatkan keterampilan menulis teks eksplanasi. Teks eksplanasi dapat disusun sesuai dengan urutan kejadian dan menggunakan kata ilmiah dalam teks eksplanasi [10].

\section{SIMPULAN}

Berdasarkan hasil yang telah dipaparkan di atas peneliti dapat mengemukakan kesimpulan sebagai berikuti ini. Penggunaan media pembelajaran berbasis powtoon pada kegiatan belajar membuat Siswa mempunyai semangat dan motivasi yang lebih. Siswa menjadi lebih kreatif dan 
inovativ lagi ketika pembelajaran berlangsung. Siswa mendapatkan hal baru dan menjadikan belajar lebih tenang dan kemudia mendapatkan pengalaman yang lebih bermakna.

Pada materi teks eksplanalis dengan menggunakan media powtoon yang bisa meluaskan hasil belajar Siswa lebih baik, hal ini ditunjukan dari hasil yang telah diteliti bahwa, terdapat berbedaan antara hasil belajar melalui pembelajaran mind map dengan hasil belajar melalui media belajar powtoon. Perbandingan ini antara $t_{\text {hitung }}(=13,611)$ lebih besar dari pada $t_{\text {tabel }}(=1,6669)$ pada $\alpha=0,05$, yang artinya hasil belajar melalui media powtoon lebih baik daripada hasil belajat melalui media mind map. Persoalan ini bisa dilihat pada rata-rata nilai hasil belajar menggunakan media powtoon sebesar 92,00, lebih besar dari rata-rata nilai hasil belajar media mind map sebesar 89,06 .

\section{REFERENSI}

[1] Dalman, H. 2016. Keterampilan Menulis. Jakarta: Rajawali Pers.

[2] Tarigan, H.G. 2008. Membaca sebagai Suatu Keterampilan Berbahasa. Bandung: Angkasa.

[3] Priyatni, Endah Tri dan T. Harsiati. 2017. Bahasa dan Sastra Indonesia Kelas XI. Jakarta: Bumi Aksara.

[4] Mahsun. 2014. Teks dalam Pembelajaran Bahasa Indonesia Kurikulum 2013. Jakarta: Rajawali Pers.

[5] Arsyad, Azhar. 2014. Media Pembelajaran. Jakarta: Rajawali Pers.

[6] Kurniawan, Prasetyo Yuli and Subyantoro Subyantoro. Pengembangan Buku Pengayaan Menulis Teks Prosedur Kompleks yang Bermuatan Nilai-Nilai Kewirausahaan. Jurnal Seloka. Diunduh pada DOI 10.15294/SELOKA.V511.12753.

[7] Yulia, Desma, Ervinalisa, Novia. 2017. Pengaruh Media Pembelajaran Powtoon pada Mata Pelajaran Sejarah Indonesia dalam Menumbuhkan Motivasi Belajar Siswa IIS Kelas X di SMA Negeri 17 Batam Tahun Pelajaran 2017/ 2018. Historia: Jurnal Program Studi Pendidikan Sejarah. Vol 2, No. 1, hal. 15-24. Diunduh pada https://www.journal.unrika.ac.id/index.php/journalhistoria/article/download/1583/1149.

[8] Buzan, Tony. 2014. Buku Pintar Mind Map. Jakarta: Gramedia Pustaka Utama.

[9] Sugiyono. 2016. Metode Penelitian Kuantitatif, Kualitatif, dan R\&D. Bandung: Alfabeta.

[10] Yohanes, Rizky Ardidavid, Mindhaudah. 2018. Penggunaan Media Video Animasi Powtoon untuk Meningkatkan Keterampilan Menulis Teks Eksplanasi Siswa Kelas XI IPA SMA PGRI Ngoro Tahun Pelajaran 2017/ 2018. SASTRANESIA, Jurnal Pendidikan Bahasa dan Sastra Indonesia. Vol. 6, No. 1, 22-36. Diunduh pada http://download.garuda.ristekdikti.go.id/article.php. 